\title{
Influences of Skill, Knowledge, Attitude, and Morality on Job Achievement
}

\author{
Heri Sudarmaji ${ }^{1}$, Luthfiyah Nurlaela ${ }^{2}$, Eko Hariadi ${ }^{3}$ \\ 1,2,3 Surabaya State University, UNESA Surabaya Indonesia.
}

\begin{abstract}
Vocational education as one of the important role holders in preparing the workforce is demanded to be able to keep up with the changing and developing market demands. Vocational education is a part of the national education system that has very strategic roles for forming skillful employees. However, in reality, it shows that not all vocational education is capable of producing quality graduates as evidenced by the lack of knowledge and skills possessed. The purpose of this research is to analyze the influences of skill, knowledge, attitude, and morality toward achievement. This research is a causal research type by a quantitative approach. The population in this research is 278 people at government agencies as a user of the graduated student from the college under the supervision of the Center for Human Resources Development on Civil Aviation (CHRDCA). The sampling technique uses total sampling. Data collection uses questionnaires. The data analysis technique used is multiple linear regression analysis. As the results of this research, there are significant and positive influences of skill, knowledge, attitude, and morality on job achievement.
\end{abstract}

Keywords: Skill, Knowledge, Attitude, Morality, Achievement

\section{INTRODUCTION}

Vocational education is a part of the national education system that has very strategic roles for forming skillful employees. From many reviews, the chances taken to have high and continual economic growths from some country will be bigger if they are supported by Human Resources who have: 1) basic knowledge and ability in self-adjustment toward developmental demands and dynamics that are going on; 2) the higher educational levels; and 3) ability skills that have backgrounds of sciences and technologies. On the other side, businessmen hope that new employees will have more bits of knowledge, more skills, and they are considerably motivated intrinsically (Bailey et al, 2004). But, the available conditions still show fewer skills owned by most new employees although the employees are vocational education graduates.

Based on reality, it becomes the responsibilities of the educational world, especially Vocational Education and Training for resulting competent graduates. According to the National Statistics Agency (2019), the number of the labor force in February 2019 was 136.18 million, up 2.24 million compared to February 2018. In line with the increase in the labor force, the Labor Force Participation Rate (TPAK) also increased by 0,12 percent point.

According to Laws Number 12 In 2012 about High Education Clause 16 verse 1, education and training in Technical Executive Unit of Air Transportation Human Resources Development Center is vocational education and training based on competencies, it means the graduates resulted are competent, skillful, and having professional performances proper with the job fields owned, they can support sub-sectors of Air Transportation safely. Vocational education is high education of diploma program that prepares students to work by certain applied skills to the applied bachelor program.

As additional information, there are 8 colleges under the supervision of CHRDCA, and they are located around Indonesia.

\section{MATERIALS AND METHODS}

\section{II.1.Research Design}

This research is a correlational design in which investigators use the correlational statistic to describe and measure the degree of association (or relationship) between two or more variables or sets of scores (Creswell, 2012).

\section{II.2.Population and Samples}

Population refers to the entire group of people, events, or things of interest that the researcher wishes to investigate (Sekaran and Bougie, 2016). The population in this research is 278 people at government agencies as a user of the graduated student from the college under the supervision of CHRDCA. This research uses the total sampling method, i.e. sample determination technique if all population members are used as samples. So, the samples used in this research are 278 people at government agencies as a user of the graduated student from the college under the supervision of CHRDCA.

\section{II.3.Variable Operational Definition}

\section{Skill $\left(\mathrm{X}_{1}\right)$}

Skill is the capability or ability to conduct some job achieved only in practices. The skill in this research is measured through indicators that refer to Yuniarsih and Suwatno (2008) are consist of : (a) Capability Dimension; (b) Personality Dimension; (c) Training Dimension. 


\section{Knowledge $\left(\mathrm{X}_{2}\right)$}

Knowledge is some information owned by someone, especially in a specific field. The knowledge in this research is measured through several indicators that refer to Yuniarsih and Suwatno (2008) are consist of: (a) Educational Dimension; (b) Experience Dimension; (c) Interest Dimension.

\section{Attitude ( $\left.\mathbf{X}_{3}\right)$}

Attitude is a syndrome or a collection of symptoms in response to a stimulus or object so that the attitude involves thoughts, feelings, attention, and other psychological symptoms (Sone, 2011). The attitude in this research is measured through several indicators are consist of: (a) receiving; (b) responding; (c) valuing; (d) responsible.

\section{Morality $\left(\mathbf{X}_{4}\right)$}

Morality is a moral character or all principles and values related to good and bad ones. The morality in this research is measured through several indicators that refer to Lennick and Kiel (2005) are consist of: (a) Integrity; (b) Responsibility; (c) Affection; (d) Forgiving.

\section{Achievement (Y)}

Achievement is the result that has been achieved from an effort that has been done and created (McShane, 2010). The achievement in this research is measured through several indicators are as follows: Internal Factor consist of (a) Intelligence; (b) Motivation; (c) Personality; and External Factor consist of (a) Home Environment; (b) School Environment.

\section{II.4.Data Type and Source}

Data collection plays a very crucial role in the statistical analysis. In research, there are different methods used to gather information, all of which fall into two categories, i.e. primary and secondary data (Douglas, 2015). The data sources used are primary data. Primary data according to Sekaran \& Bougie (2016) is a way in which data collected from sources on the variable of interest for the specific purpose of the study.

\section{II.5.Data Collection Method}

The data collection method in this research uses survey direct method, for instance distributing questionnaires or facing respondents directly that meet requirements.

\section{II.6.Data Analysis Technique}

According to Cooper \& Schindler (2014), multiple regressions are statistical techniques used to analyze the relationship between a single dependent variable and a few independent variables. Thus the objective of using multiple regressions is to predict the dependent variable from one or more independent variables. However, if the research only involves one dependent variable and one independent variable, the statistics technique is referred to as a simple regression. Multiple linear regression analysis is a linear relationship between two or more independent variables (skill, knowledge, attitude, and morality) and a dependent variable (achievement). The multiple linear regression similarity is as follows:

\section{$Y=a+b 1 X 1+b 2 X 2+b n X n$}

Notes :

$$
\begin{aligned}
& \mathrm{Y}=\text { Dependent variable [the values predicted] } \\
& \mathrm{a}=\text { Constant [the value of } \mathrm{Y} \text { if } \mathrm{X} 1 \text { and } \mathrm{X} 2 \text { is }=0 \text { ) } \\
& \mathrm{b}=\begin{array}{l}
\text { Regression coefficient } \text { [increase or decrease } \\
\text { values] }
\end{array} \\
& \mathrm{X}=\text { Independent variables }
\end{aligned}
$$

\section{Correlation Coefficient $[R]$ and Determination Coefficient $\left[\mathbf{R}^{2}\right]$}

The correlation coefficient $[\mathrm{R}]$ is used to know the level of the closeness between independent variables and the dependent variable. From the results of the correlation coefficient, it can be known if the relationship between independent variables (Y) and the dependent variable is close or not. The coefficient of determination is used to measure the ability of the model to explain the variation in the dependent variable. (Snall, 2010) The determination coefficient value is between zero and one. The small value of $\mathrm{R}^{2}$ means that independent variable abilities in explaining dependent variable variations are very limited. The value that is close to one means that independent variables give almost all information needed to predict dependent variable variations.

\section{Hypothesis Test \\ a. T-test}

The purpose of using a significance test is to know whether there is a significant relationship between the dependent variable and the independent variables (Cooper \& Schindler, 2014). The writer will compare the $t$ value gotten from the calculation with the $t$ value from the table. If $t$ value calculation is higher than the significance level of 0.05 , then it can be said that the independent variable has a significant relationship to the dependent variable.

\section{b. F-test}

F-test is used to show if all independent variables entered into the model have influences simultaneously toward the dependent variable If the significance value is $<0.05$, it 
means that independent variables influence significantly simultaneously toward the dependent variable. If the significance value is $>0.05$, it means that independent variables do not influence significantly simultaneously toward the dependent variable (Lohr, 2009).

\section{RESULTS AND DISCUSSION}

\section{III.1. Data Analysis}

\section{Multiple Linear Regression Analysis}

Based on the data processing calculation resulted from the SPSS program, so it is achieved multiple linear regression similarities in Table 1.

Table 1. Multiple Linear Regression Analysis Results

\begin{tabular}{lllll}
\hline Variable & B & Std.Error & T $_{\text {calculation }}$ & $\mathbf{t}_{\text {Sig. }}$ \\
\hline (Constant) & 0,803 & 0,171 & & \\
\hline Skill & 0,239 & 0,050 & 4,798 & 0,000 \\
\hline Knowledge & 0,153 & 0,053 & 2,880 & 0,004 \\
\hline Attitude & 0,182 & 0,055 & 3,300 & 0,001 \\
\hline Morality & 0,190 & 0,056 & 3,368 & 0,001 \\
\hline $\mathrm{R}=$ & 0,719 & $\mathrm{R}_{\text {Square }}$ & $=$ & 0,517 \\
$\mathrm{~F}_{\text {calculation }}=$ & 72,965 & $\mathrm{~F}_{\text {Sig }}$ & $=$ & 0,000 \\
\hline
\end{tabular}

Based on the calculation results above, it is achieved significant multiple linear regression similarity as follows:

$Y=0.803+0.239 X_{1}+0.153 X_{2}+0.182 X_{3}+0.190 X_{4}+\ldots . e$

Constant 0.803 which shows the total variable of achievement influenced by variables of skill, knowledge, attitude, and morality, or independent variables is $=0$, so the value of achievement is as 0.803 , by the assumption that other variables are constant. The variable of skill has a value of 0.239 . It means if the variable of skill increases as one unit, it will add achievement as 0.239 unit. The value is above zero, it means that it has a positive value so the higher the skill, so the higher the achievement.

Variable of knowledge has the value as 0.153 , it means if the variable of knowledge increases as one unit, so it will add achievement as 0.153 unit. Besides that, the higher the knowledge, so the higher the Achievement. Variable of attitude has the value as 0.182 , it means if the variable of attitude increases as one unit, it will add achievement as 0.182 unit. Besides that, the higher the altitude, so the higher the Achievement. Variable of morality has the value as 0.190 , it means if the variable of morality increases as one unit, it will add achievement as 0.190 unit. Besides that, the higher the morality, so the higher the Achievement.

\section{Multiple Correlation Coefficient (R) and Multiple Determination $\left(\mathbf{R}^{2}\right)$}

Correlation coefficient value [R] shows how close is the relationship between independent variables (variables of Skill $\left(\mathrm{X}_{1}\right)$, Knowledge $\left(\mathrm{X}_{2}\right)$, Attitude $\left(\mathrm{X}_{3}\right)$, and Morality $\left.\left(\mathrm{X}_{4}\right)\right)$ and dependent variable as Achievement (Y), the total correlational coefficient value is 0,719 . The value shows that the variable relation of Skill $\left(\mathrm{X}_{1}\right)$, Knowledge $\left(\mathrm{X}_{2}\right)$, Attitude $\left(\mathrm{X}_{3}\right)$, and Morality $\left(\mathrm{X}_{4}\right)$ ) toward the variable of Achievement $(\mathrm{Y})$ is very strong because the correlational value of 0.719 is close to number one.

Determination coefficient value or $\mathrm{R}^{2}$ is used to measure how far is the ability of the model in explaining dependent variable variation, i.e. variable of achievement. The results from the SPSS calculation show that the value of $\mathrm{R}^{2}$ is $=0.517$, it means that $51.7 \%$ of achievement can be explained by variables of Skill $\left(\mathrm{X}_{1}\right)$, Knowledge $\left(\mathrm{X}_{2}\right)$, Attitude $\left(\mathrm{X}_{3}\right)$, and Morality $\left(\mathrm{X}_{4}\right)$. Whereas the rest as $48.3 \%$ is influenced by other variables outside the model research.

\section{F-Test [Simultaneous Test ]}

Based on Table 3, the total significance value is 0.0000 , it means $<0,05$. This case shows that $\mathrm{H} 0$ is rejected and $\mathrm{H} 1$ is accepted. So, the independent variables that consist of Skill $\left(\mathrm{X}_{1}\right)$, Knowledge $\left(\mathrm{X}_{2}\right)$, Attitude $\left(\mathrm{X}_{3}\right)$, and Morality $\left(\mathrm{X}_{4}\right)$ influence significantly simultaneously toward Achievement (Y).

\section{Hypothesis Testing}

For the testing hypothesis, it is used t-test that shows influences partially from each independent variable toward the dependent variable.

a. T-test [partial] in the variable of Skill $\left(\mathrm{X}_{1}\right)$

Based on the research data processing results, it is achieved the value of sig as $0,000<0,05$, so $\mathrm{H} 0$ is rejected, so the conclusion is variable of Skill $\left(\mathrm{X}_{1}\right)$ has significant and positive influences toward Achievement.

b. T-test [partial] in the variable of Knowledge $\left(\mathrm{X}_{2}\right)$

Based on the research data processing results, it is achieved the value of sig as $0,004<0,05$, so $\mathrm{H} 0$ is rejected, so the conclusion is variable of Knowledge $\left(\mathrm{X}_{2}\right)$ has significant and positive influences toward Achievement.

c. T-test [partial] in the variable of Attitude $\left(\mathrm{X}_{3}\right)$

Based on the research data processing results, it is achieved the value of sig as $0,001<0,05$, so $\mathrm{H} 0$ is rejected, so the conclusion is variable of Attitude $\left(\mathrm{X}_{3}\right)$ has significant and positive influences toward Achievement.

d. T-test [partial] in the variable of Attitude Morality $\left(\mathrm{X}_{4}\right)$ 
Based on the research data processing results, it is achieved the value of sig as $0,004<0,05$, so $\mathrm{H} 0$ is rejected, so the conclusion is variable of Morality $\left(\mathrm{X}_{4}\right)$ has significant and positive influences toward Achievement.

\section{III.2. The Effect of Skill on Job Achievement}

Based on the research results, it is obtained that the Skill $\left(\mathrm{X}_{1}\right)$ variable has significant and positive influences on job Achievement. This can be seen from the value of sig as 0,000 $<0.05$, so $\mathrm{H0}$ is rejected with the significance level of $5 \%$, which means that better skills will contribute greatly in improving the job achievement. The findings of this study indicate that skills have an important role in improving job achievement. But in reality, there are high numbers of unskill workers (workers who do not have competencies in their fields). So for that issue, the college under the supervision of CHRDCA should be more focused on improving the skills of its graduates.

\section{III.3. The Effect of Knowledge on Achievement}

Based on the research results obtained, the Knowledge (X2) variable has significant and positive influences toward Achievement. This can be seen from the value of sig as 0.004 $<0.05$, so $\mathrm{H} 0$ is rejected in the significance level of $5 \%$, which means that the higher knowledge will provide a major contribution in improving the job achievement.

The findings show that knowledge plays an important role in improving job achievement. But in existing conditions, the number of skilled workers and expert workers is known to be less than unskill workers. If it is related to the results of this study, the colleges under the supervision of CHRDCA must increase the knowledge of their students.

\section{III.4. Effects of Attitude on Achievement}

Based on the research results obtained, the Attitude (X3) variable has significant and positive influences toward Achievement. This can be seen from the value of sig as 0.001 $<0.05$, so $\mathrm{H} 0$ is rejected at the significance level of $5 \%$, which means that the better attitude of students will encourage an increase in job achievement.

The findings show that attitude can significantly improve job achievement. But up to now, vocational education has not met expectations of improving the quality of student graduates. When linked to the results of this study, it is very important for the college under the supervision of CHRDCA should improve the attitude of their students that consists of responsibility, honesty, discipline, good communication, and the importance of teamwork.

\section{III.5. Effect of Morality on Achievement}

Based on the research results obtained, the Morality (X4) variable has significant and positive influences toward Achievement. This can be seen from the value of sig as 0.004
$<0.05$, so $\mathrm{H} 0$ is rejected at the significance level of $5 \%$, which means the better the morale of students will also improve the job achievement.

The result of the study shows that morality has a contribution to increasing job achievement. As we know, vocational education has not met expectations of improving the morality of graduate students. So it is very important for the college under the supervision of CHRDCA to have more concern about the morality of each student.

\section{CONCLUSIONS}

Based on the analysis results and the research discussions about the influences of skill, knowledge, attitude, and morality on job achievement, so it can be taken the conclusions, they are:

1. There are significant and positive influences of skill on job achievement

2. There are significant and positive influences of knowledge on job achievement

3. There are significant and positive influences of attitude on job achievement

4. There are significant and positive influences of morality on job achievement

5. The highest influence is Skill compare to another variable

\section{ACKNOWLEDGEMENT}

The authors greatly acknowledge the support from Surabaya State University (UNESA) Surabaya Indonesia for providing the necessary resources to carry out this research work. The authors are also grateful to the anonymous reviewers and journal editorial board for their many insightful comments, which have significantly improved this article.

\section{REFERENCES}

[1] Bailey. T, et al. (2004). Working Knowledge: WorkBased Learning and Education Reform. New York: Routledge Falmer.

[2] Badan Statistik Nasional. (2019). BPS : Angka Partisipasi Kerja meningkat pada Februari 2019. Di akses melalui situs https://www.gatra.com/detail/news/414167/ekonomi/bp s--angka-partisipasi-kerja-meningkat-pada-februari2019

[3] Creswell, John W. (2012). Research Design Pendekatan Kualitatif,. Kuantitatif, dan Mixed. Yogyakarta: Pustaka Pelajar.

[4] Cooper, D.R. dan Schindler, P.S. (2014). Business Research Methods. McGraw-Hill, New York.

[5] Douglas. B. (2015) The Theory and Practice of 
International Journal of Engineering Research and Technology. ISSN 0974-3154, Volume 13, Number 11 (2020), pp. $3372-3376$

(C) International Research Publication House. https://dx.doi.org/10.37624/IJERT/13.11.2020.3372-3376

Development Education: A Pedagogy for Global Social Justice. New York: Routledge.

[6] Lennick, D. and Kiel, F. (2005) Moral Intelligence. Wharton University of Pennsylvania, Philadelphia, 16.

[7] Robbins, Stephen. (2010). What is Organizational Behavior, USA Pearson.

[8] Sekaran, U., \& Bougie, R. (2016). Research methods for business: a skill-building approach ( $7^{\text {th }}$ ed.). Haddington: John Wiley \& Sons.

[9] Snall Scott, \& George Bohlander, (2010). Principles of Human Resource Management 15th Edition, Ohio: South-Western Cengage Learning.

[10] Lohr, Sharon L., (2009). Handbook of Statistics, Volume 29, Boston: Elsevier.

[11] Sone, Raymond J., (2011). Human Resource Management Seventh Edition Queensland, John Wiley \& Sons Australia, Ltd.

[12] McShane, SL. and Marry Ann Von Glinow, (2010), Organizational Behavior, 5th Edition, Boston: McGraw-Hill.

[13] Yuniarsih, T., dan Suwatno. (2008). Manajemen Sumber Daya Manusia. Bandung: CV. Alfabeta. 